\title{
Genetic diversity in Spanish donkey breeds using microsatellite DNA markers
}

\author{
José Aranguren-Méndez ${ }^{\mathrm{a}, \mathrm{b}}$, Jordi Jordana ${ }^{\mathrm{a}, *}$, \\ Mariano GoMez ${ }^{\mathrm{c}}$ \\ ${ }^{a}$ Unitat de Genètica i Millora Animal, Departament de Ciència Animal i dels \\ Aliments, Facultat de Veterinària, Universitat Autònoma de Barcelona, \\ 08193-Bellaterra, Barcelona, Spain \\ ${ }^{\mathrm{b}}$ Universidad del Zulia, Facultad de Ciencias Veterinarias, Departamento de \\ Producción Animal, Maracaibo 4001-A, Venezuela \\ ${ }^{\mathrm{c}}$ Servicio de Ganadería, Diputación Foral de Bizkaia, Avda. Lehendakari Aguirre, \\ $9,2^{\circ}, 48014$ Bilbao, Spain
}

(Received 27 November 2000; accepted 23 April 2001)

\begin{abstract}
Genetic diversity at 13 equine microsatellite loci was compared in five endangered Spanish donkey breeds: Andaluza, Catalana, Mallorquina, Encartaciones and ZamoranoLeonesa. All of the equine microsatellites used in this study were amplified and were polymorphic in the domestic donkey breeds with the exception of HMS1, which was monomorphic, and ASB2, which failed to amplify. Allele number, frequency distributions and mean heterozygosities were very similar among the Spanish donkey breeds. The unbiased expected heterozygosity $\left(\mathrm{H}_{\mathrm{E}}\right)$ over all the populations varied between 0.637 and 0.684 in this study. The low $\mathrm{G}_{\mathrm{ST}}$ value showed that only $3.6 \%$ of the diversity was between breeds $(P<0.01)$. Significant deviations from Hardy-Weinberg equilibrium were shown for a number of locuspopulation combinations, except HMS5 that showed agreement in all analysed populations. The cumulative exclusion probability (PE) was 0.999 in each breed, suggesting that the loci would be suitable for donkey parentage testing. The constructed dendrogram from the $\mathrm{D}_{\mathrm{A}}$ distance matrix showed little differentiation between Spanish breeds, but great differentiation between them and the Moroccan ass and also with the horse, used as an outgroup. These results confirm the potential use of equine microsatellite loci as a tool for genetic studies in domestic donkey populations, which could also be useful for conservation plans.
\end{abstract}

donkey / endangered breed / microsatellite / diversity / genetic variability

\section{INTRODUCTION}

The local Spanish donkey breeds (Equus asinus) Andaluza, Catalana, Encartaciones, Mallorquina and Zamorano-Leonesa have suffered a substantial decrease in population size which might cause high levels of inbreeding

\footnotetext{
* Correspondence and reprints
}

E-mail: Jordi.Jordana@uab.es 
resulting in inbreeding depression and increasing the risk of breed extinction. The principal cause of the great reduction in population size of up to $80 \%$ has been the intense mechanisation of agriculture which took place in Spain during the 60s and the 70s. These Spanish donkey breeds have been officially recognised as breeds for a long time. Currently, the number of animals recorded among these five breeds is very low, and they are included in the FAO (Food and Agriculture Organisation of the United Nations) list of domestic animal breeds to be conserved (FAO, DAD-IS http://fao.org/dadis). At present, the Spanish donkey breeds comprise approximately 100 to 200 females each (Breed Associations personal communications). These figures fit into the category of an endangered breed as proposed by the FAO Expert Consultation [2]. Without immediate action, the effective population size of these five Spanish breeds will be inadequate to prevent constant genetic loss at each generation [8].

The origin of the modern Spanish donkey breeds remains uncertain. According to several authors $[1,12,13,15]$ current Spanish donkeys seem to derived from two ancestral sources: the Nubian ass (Equus asinus africanus), which gave rise to the Andaluza breed $[3,16,40]$, and secondly, the Somalian ass (Equus asinus somaliensis) which gave rise to the donkeys of Southwest Asia and probably also to the majority of European breeds, among which the Catalana, Mallorquina, Encartaciones and Zamorano-Leonesa breeds [15].

Notwithstanding this, Dechambre and Sanson, as cited by several authors [3, $24,37,40]$, support the theory of two different ancestral sources: one which would correspond to the Equus asinus africanus, originating from Northeast Africa, and the other one, the Equus asinus europeus, whose area of origin is the Mediterranean Basin, in particular the Balearic Isles, which would have given rise to the majority of European donkey breeds, including the four Spanish breeds mentioned in the previous paragraph.

The conservation of genetic variation found in these minor livestock breeds is a growing world-wide concern due to the increasing risk of breed loss. Recently, many studies of breed conservation have used allele frequencies for several DNA markers, such as microsatellites $[19,26,36]$.

Very little literature reporting microsatellite data in domestic donkeys exists; only Breen et al. [10], using a set of 13 microsatellite loci isolated from the domestic horse, verified that they were well-amplified in eight individuals. In addition, Bellone and co-workers [7] reported studies in one French donkey breed (Baudet du Poitou) with nine microsatellite loci. Finally, we also performed studies with the Catalonian donkey breed [22,23]. In the present work, 15 equine microsatellite loci were analysed in 5 Spanish donkey breeds, in order to study the genetic variability both within and between these breeds. 


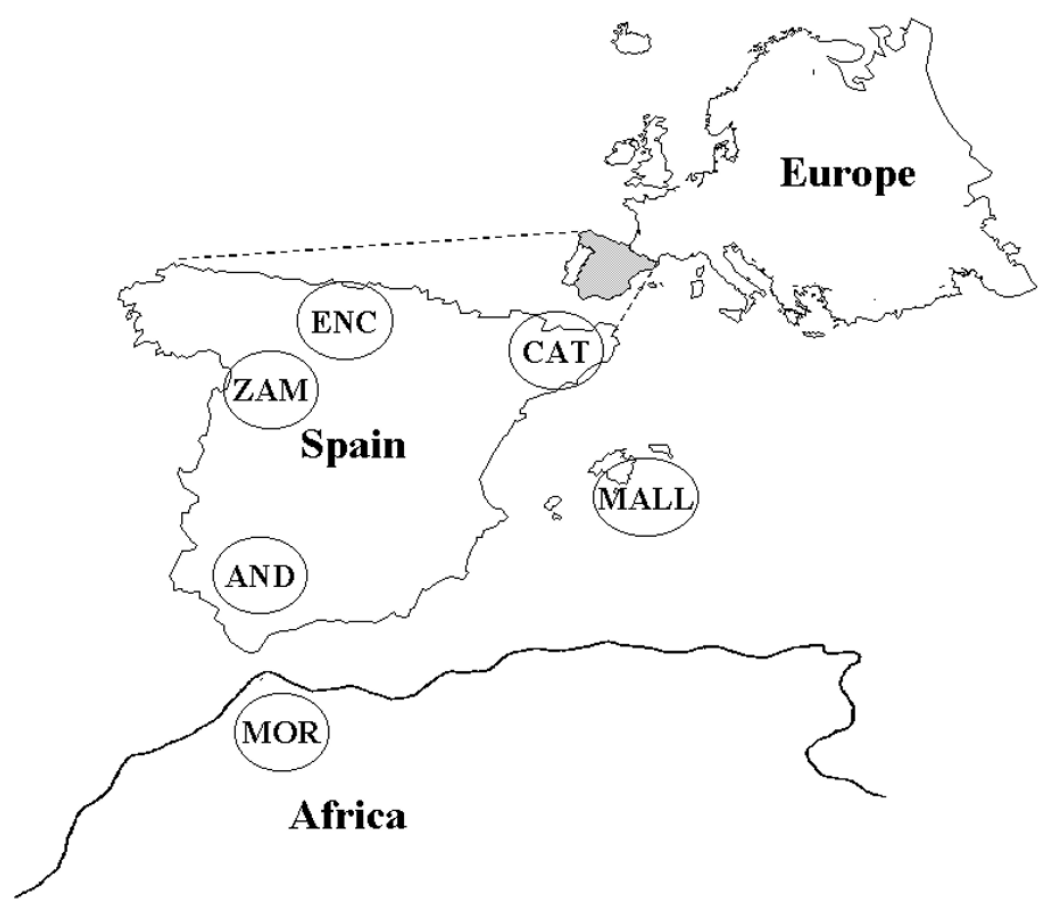

Figure 1. Geographical location of the Spanish donkey breeds.

\section{MATERIALS AND METHODS}

\subsection{Population samples}

The number of individuals sampled, of both sexes, was 87 Andaluza (AND), 140 Catalana (CAT), 104 Mallorquina (MALL), 74 Encartaciones (ENC) and 108 Zamorano-Leonesa (ZAM) representing 75 and $95 \%$ of the whole population in each case. The area of main distribution of these indigenous Spanish breeds is shown in Figure 1. In addition, 9 Moroccan asses (MOR) were used as genuine members of E. asinus africanus, and 24 horses of the Merens breed (E. caballus) were used as an outgroup. Donkey DNA was prepared from whole blood according to standard methods involving lysates of the washed white-cells and phenol-chloroform-isoamylalcohol (25:24:1) extraction [4].

\subsection{Microsatellite markers}

The 15 microsatellite loci studied were AHT4, AHT5 [6], ASB2 [11], HMS1, HMS2, HMS3, HMS5, HMS6, HMS7 [17], HTG4, HTG6 [14], HTG7, HTG10 [25], HTG15 [5] and VHL20 [41]. 


\subsection{Multiplex PCR conditions}

The 15 microsatellites were amplified in three multiplexes using fluorescently-labelled primers. The first multiplex included microsatellites ASB2, HMS3, HMS6, HTG6, HTG10, and VHL20. The second was composed of AHT4, AHT5, HMS2, HMS7 and HTG7, while the third contained HMS1, HMS5, HTG15 and HTG4. Multiplex PCRs were carried out in $15 \mu \mathrm{L}$ reactions containing $30 \mathrm{ng}$ of genomic DNA, $200 \mu \mathrm{M}$ of dNTP, $0.5 \mu \mathrm{L}$ of AmpliTaq Gold $\left(5 \mathrm{U} \cdot \mu \mathrm{L}^{-1}\right), 1.5 \mathrm{mM}$ of $\mathrm{MgCl}_{2}$ and $0.5 \mu \mathrm{L}$ of each primer (AHT4, ASB2, HMS2, HMS3, HTG6, HTG7, HTG10), $0.4 \mu \mathrm{L}$ of the primer (AHT5, HMS6 and HMS7) while $0.3 \mu$ L of primer VHL20 (StockMarks ${ }^{\circledR}$ for Horses, Equine Paternity PCR Typing Kit, PE Applied Biosystems, Foster City, CA), and finally, $0.20 \mu \mathrm{M}$ of primers HMS1, HMS5, HTG4 and HTG15. PCR was carried out in a 9700 GeneAmp PCR system (Perkin Elmer) by an initial denaturation at $95^{\circ} \mathrm{C}$ for $10 \mathrm{~min}$, followed by 30 cycles at $95^{\circ} \mathrm{C}$ for $30 \mathrm{~s}, 60^{\circ} \mathrm{C}$ for $30 \mathrm{~s}$ and $72^{\circ} \mathrm{C}$ for $60 \mathrm{~s}$. The thermal profile ended with a final extension at $72{ }^{\circ} \mathrm{C}$ for $60 \mathrm{~min}$. PCR products were detected by capillary electrophoresis using an Applied Biosystems 310 DNA Sequencer with GENESCAN Analysis software (ABI), using the ROX 350 bp internal-size standard.

\subsection{Statistical analyses}

Allele frequencies (available from the authors on request) and mean heterozygosity values for each polymorphic locus were obtained using the BIOSYS-2 computer programme [38]. The test of genotype frequencies for deviation from the Hardy-Weinberg Equilibrium (HWE) was calculated using the exact test of the GENEPOP 3.1d computer programme [32], using the Markov-chain method [18]. Polymorphic information content (PIC) was calculated for each microsatellite locus according to Botstein et al. [9], and the probability of exclusion (PE) was determined for all informative markers [20].

The average expected heterozygosity for each population $\left(\mathrm{H}_{\mathrm{S}}\right)$, the gene diversity in the total population $\left(\mathrm{H}_{\mathrm{T}}\right)$, and the coefficient of gene differentiation $\mathrm{G}_{\mathrm{ST}}$ [27] were estimated using the computer programme DISPAN [30], and tested by permutation test. Differences in average heterozygosities among breeds were assessed using the ANOVA test of the SAS ${ }^{\circledR}$ package [35].

Genetic distances and phylogenetic trees among populations were obtained with the distance measure $\mathrm{D}_{\mathrm{A}}$ [29]. Takezaki and Nei [39] suggested the $\mathrm{D}_{\mathrm{A}}$ distance for making phylogenetic trees when the interest of the study mainly focused on the topology rather than evolutionary time. Distance data was analysed with the neighbour-joining (NJ) method of clustering [34]. The NJ method produces only unrooted trees. For this reason we included the data for the Merens breed population as an outgroup to root the tree. The robustness of the dendrogram was evaluated by bootstrap resampling of loci (1 000 replicates). All these calculations were carried out using the DISPAN package [30]. 
Table I. Total number and range of observed alleles, average heterozygosity $\mathrm{H}_{\mathrm{S}}$ and $\mathrm{H}_{\mathrm{T}}$, coefficient of differentiation $\mathrm{G}_{\mathrm{ST}}$, PIC and PE, in Spanish donkey breeds.

\begin{tabular}{lccccccc}
\hline Microsatellite $^{\text {No.A. }}{ }^{1}$ & S. Range $^{2}$ & $\mathrm{H}_{\mathrm{T}}$ & $\mathrm{H}_{\mathrm{S}}$ & $\mathrm{G}_{\mathrm{ST}}$ & $\mathrm{PIC}^{3}$ & $\mathrm{PE}^{4}$ \\
\hline AHT4 & 15 & $126-160$ & 0.773 & 0.753 & $0.031^{* * * *}$ & 0.71 & 0.55 \\
AHT5 & 14 & $126-156$ & 0.907 & 0.852 & $0.037^{* * *}$ & 0.85 & 0.74 \\
ASB2 & - & - & - & - & - & - & - \\
HMS1 & 1 & 165 & - & - & - & - & - \\
HMS2 & 10 & $229-247$ & 0.709 & 0.714 & $0.016^{* * *}$ & 0.65 & 0.47 \\
HMS3 & 7 & $152-170$ & 0.618 & 0.603 & $0.044^{* * *}$ & 0.51 & 0.32 \\
HMS5 & 3 & $105-109$ & 0.278 & 0.336 & $0.109^{* * *}$ & 0.20 & 0.10 \\
HMS6 & 6 & $151-167$ & 0.649 & 0.613 & $0.041^{* * *}$ & 0.54 & 0.33 \\
HMS7 & 7 & $165-177$ & 0.626 & 0.601 & $0.031^{* * *}$ & 0.53 & 0.33 \\
HTG4 & 5 & $167-175$ & 0.495 & 0.439 & $0.048^{* * *}$ & 0.40 & 0.21 \\
HTG6 & 11 & $76-102$ & 0.817 & 0.714 & $0.053^{* * *}$ & 0.73 & 0.55 \\
HTG7 & 13 & $134-164$ & 0.843 & 0.800 & $0.030^{* * *}$ & 0.80 & 0.65 \\
HTG10 & 12 & $85-107$ & 0.837 & 0.790 & $0.035^{* * *}$ & 0.78 & 0.63 \\
HTG15 & 7 & $116-136$ & 0.751 & 0.746 & $0.014^{* * *}$ & 0.70 & 0.51 \\
VHL20 & 4 & $75-99$ & 0.579 & 0.597 & $0.035^{* * *}$ & 0.50 & 0.31 \\
All loci & & & 0.683 & 0.658 & $0.036^{* * *}$ & & 0.999 \\
& & & $( \pm 0.170)$ & $( \pm 0.147)$ & $( \pm 0.023)$ & & \\
\hline
\end{tabular}

*** $P<0.001$.

1 Total number of observed alleles. -: Failed to amplify.

${ }^{2}$ Size range of the observed allele in bp.

3 Polymorphism information content.

${ }^{4}$ Exclusion probability.

A: Monomorphic.

\section{RESULTS}

The equine microsatellites were all well-amplified in the donkey, with the exception of locus ASB2, which failed to amplify. All amplified loci were polymorphic except HMS1, which was monomorphic (165 bp) in all breeds. The number of alleles varied between 3 (HMS5) and 15 (AHT4) (Tab. I), with generally little difference between the breeds (data not shown). The average gene diversity $\mathrm{H}_{\mathrm{T}}$ [27] over all loci was $0.683 \pm 0.170$ while, for individual loci, it ranged from 0.278 (HMS5) to 0.907 (AHT5).

The average expected heterozygosity $\mathrm{H}_{\mathrm{S}}$ across all loci in the total sample was $0.658 \pm 0.147$ and ranged from 0.336 (HMS5) to 0.852 (AHT5). The average coefficient of gene differentiation $\left(\mathrm{G}_{\mathrm{ST}}\right)$ over the 13 loci was $0.036 \pm$ $0.023(P<0.01)$. The $\mathrm{G}_{\mathrm{ST}}$ values for single loci ranged from 0.014 for HTG15 to 0.109 for HMS5. The PIC and the exclusion probability (PE) are given in Table I. The combined probability of exclusion was 0.999 , across the whole sample as well as for each breed. 
Table II. Sample size, number of alleles per locus and heterozygosity ( \pm standard errors) averaged over 13 microsatellites in 5 donkey populations.

\begin{tabular}{lcccc}
\hline & & & \multicolumn{2}{c}{ Mean heterozygosity } \\
\cline { 3 - 5 } Population & Mean sample & Mean No. of & Observed & Expected* \\
& size per locus & alleles per locus & & \\
\hline Andaluza & 87 & $7.0 \pm 1.0$ & $0.532 \pm 0.052$ & $0.679 \pm 0.034$ \\
Catalana & 140 & $7.1 \pm 1.0$ & $0.528 \pm 0.062$ & $0.663 \pm 0.055$ \\
Mallorquina & 104 & $7.5 \pm 0.9$ & $0.570 \pm 0.063$ & $0.637 \pm 0.054$ \\
Encartaciones & 74 & $7.4 \pm 1.0$ & $0.564 \pm 0.066$ & $0.646 \pm 0.059$ \\
Zamorano-Leonesa & 108 & $7.3 \pm 1.1$ & $0.539 \pm 0.058$ & $0.684 \pm 0.044$ \\
Means & & $7.2 \pm 1.0$ & $0.546 \pm 0.060$ & $0.654 \pm 0.048$ \\
\hline
\end{tabular}

${ }^{*}$ Unbiased estimate [28].

Among Spanish donkeys the mean number of alleles per locus ranged from 7.0 in the Andaluza breed to 7.5 in the Mallorquina breed (Tab. II). The mean observed heterozygosity $\left(\mathrm{H}_{\mathrm{O}}\right)$ showed a range of values from 0.528 in the Catalana breed to 0.570 in the Mallorquina breed. Average expected heterozygosities $\left(\mathrm{H}_{\mathrm{E}}\right)$ ranged from 0.637 in the Mallorquina breed to 0.684 in the Zamorano-Leonesa breed, and were not significantly different. The number of private alleles varied among the five breeds: 1 in Andaluza (HMS6: $151 \mathrm{bp}$ ), 4 in Encartaciones (one in HTG4: $175 \mathrm{bp}$; AHT4: $146 \mathrm{bp}$; and two in HTG6: 98 and $100 \mathrm{bp}$ ), 2 in Mallorquina (HMS3: $160 \mathrm{bp}$; HTG15: $136 \mathrm{bp}$ ) and one in Zamorano-Leonesa (HTG4: $173 \mathrm{bp}$ ). Only one private allele showed a frequency $>5 \%$ (HTG6; 100 bp with a frequency of $10.8 \%$, in the Encartaciones breed).

HWE was tested for all breed-locus combinations. Of the 65 contrasts, 48 tests gave significant deviations from HWE showing a significant heterozygote deficit. Only 17 tests showed agreement with HWE, corresponding to the Andaluza, Encartaciones and Mallorquina breeds for four microsatellites (HMS3, HMS5, HTG6 and VHL20; HMS3, HMS5, HTG10 and VHL20; and AHT4, HMS3, HMS5 and HMS6, respectively), the Zamorano-Leonesa breed for three microsatellites (HMS5, HTG10 and VHL20) and the Catalana breed for two microsatellites (HMS5 and HTG15). Only one of the microsatellites (HMS5) showed agreement with $\mathrm{H}-\mathrm{W}$ proportions in all analysed populations.

The $\mathrm{D}_{\mathrm{A}}$ distance, using 13 microsatellites, ranged between 0.057 and 0.093 for the Spanish donkey breeds (Tab. III). A neighbour-joining tree was constructed, and the reliability of the obtained tree was examined by 1000 bootstrap replicates (Fig. 2). The most robust features of the topology were the CatalanaMallorquina cluster (70\% support) and the cluster (77\% support) formed by Andaluza and the four black coated breeds (CAT, ENC, MALL and ZAM) which are all from the North of Spain. 
Table III. Matrix of $\mathrm{D}_{\mathrm{A}}$ genetic distance among five Spanish donkey breeds (Moroccan ass and horse).

\begin{tabular}{lcccccc}
\hline & AND & CAT & MALL & ENC & ZAM & Horse \\
\hline Moroccan & 0.119 & 0.197 & 0.154 & 0.136 & 0.123 & 0.685 \\
Andaluza & & 0.093 & 0.078 & 0.063 & 0.057 & 0.629 \\
Catalana & & & 0.069 & 0.071 & 0.079 & 0.665 \\
Mallorquina & & & & 0.067 & 0.062 & 0.649 \\
Encartaciones & & & & & 0.059 & 0.640 \\
Zamorano-Leonesa & & & & & & 0.644 \\
\hline
\end{tabular}

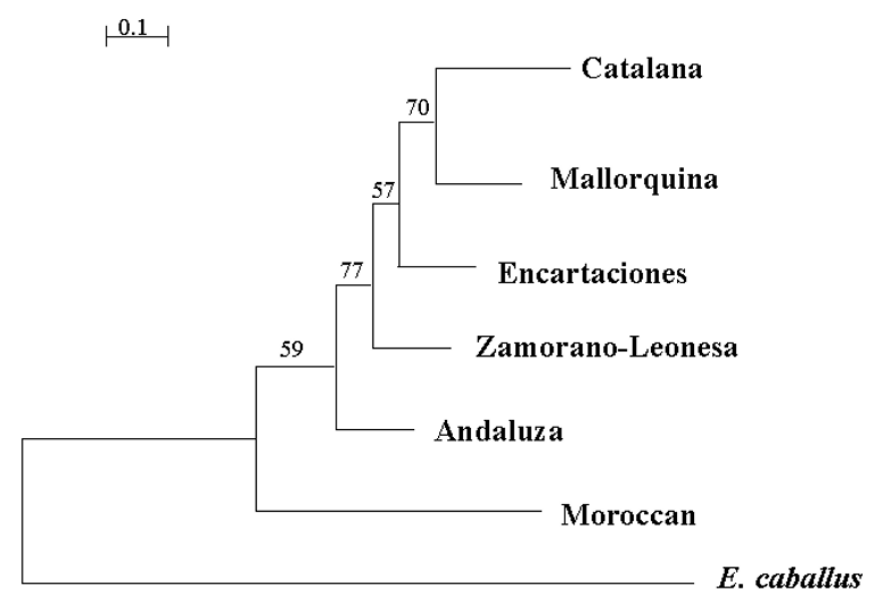

Figure 2. Dendrogram showing the genetic relationships among donkey breeds using the neighbour-joining method and the $\mathrm{D}_{\mathrm{A}}$ genetic distance, measured with 13 microsatellite loci. The number at the forks indicate the percentage of group occurrence in a bootstrap resampling of 1000 trees.

The low genetic distances among Spanish breeds indicated a close relationship among these populations. The phylogenetic tree was constructed based on the matrix of $\mathrm{D}_{\mathrm{A}}$ values using the Merens horse breed as an outgroup, and the Moroccan ass breed as the reference population for the Spanish breeds.

\section{DISCUSSION}

The average number of alleles and the expected heterozygosities $\left(\mathrm{H}_{\mathrm{E}}\right)$ were similar for all breeds, indicating that there are no appreciable differences in the level of genetic variability among the Spanish breeds. These results are comparable to the previous values reported in Catalonian donkeys [23] and the Baudet du Poitou breed [7]. 
Average genetic differentiation $\left(\mathrm{G}_{\mathrm{ST}}\right)$ among the breeds was $3.6 \%$, a relatively low but significant $(P<0.01)$ value. All loci were contributing to that differentiation. The global PE value of 0.999 for each breed makes it extremely unlikely that false parentage would not be recognised. These markers are therefore an effective tool in donkey parentage verification. The genetic relationships among the populations correspond with the geographical distribution of the breeds studied. The dendrogram (Fig. 2) groups all of the Spanish donkeys into one cluster (59\% support).

Within the Spanish breeds, the four black coated populations (CAT, ENC, MALL and ZAM) form a cluster (77\% support), supporting the hypothesis of a common ancestral past from E. a.europeus. The Catalana and Mallorquina breeds are the most closely related, supporting both the historic and the archaeological evidence that they show common ancestry [31,33].

All sources agree that the Andaluza breed descended from the primitive ass of North Africa (E. a. africanus) which could have been introduced into the South of the Iberian Peninsula through the Straits of Gibraltar [3,13, 15,37]. However, our data fails to clearly position the Andaluza breed within our tree. Further investigations involving more European and African donkey populations, as well as the analysis of ${ }_{\mathrm{mt}} \mathrm{DNA}$, which could show a possible introgression of African haplotypes into European populations would be useful to clarify this point. Nevertheless, we have concluded that the analyses of genetic markers such as microsatellite sequences are very valuable for the study of genetic variability in donkey populations and to contribute to the establishment of their own conservation plans [21].

\section{ACKNOWLEDGEMENTS}

This study was made possible by the financial support of the CICYT (project AGF98-0503) and the DARP (Generalitat de Catalunya) ; we are also grateful to the Breed Associations of Spanish donkeys for their helpful co-operation and assistance during sample collection. Furthermore, we would like to thank Chuck Simmons for the English revision and A. Clop, H. Yahyaoui and R. Pena for suggestions on the manuscript.

\section{REFERENCES}

[1] Adametz L., Zootecnia General, Ed. Labor, Madrid, 1943.

[2] Anonymous, Recommendations of the FAO expert consultation, in: Hodges J. (Ed.), The management of global animal genetics resources, Food and Agriculture Organisation of the United Nations, Rome, 1992, pp. 1-24.

[3] Aparicio G., Zootecnia Especial. Etnología compendiada. Imprenta Moderna, Córdoba, 1960. 
[4] Ausubel F.M., Brent R., Kingston R.E., Moore D.D., Seidman G.G., Smith J.A., Struhl K., Current protocols in molecular biology, Green Publishing Associates and Wiley-Interscience, New York, 1987.

[5] Bailey E., Graves K.T., Cothran E.G., Reid R., Lear T.L., Ennis R.B., Syntenymapping horse microsatellite markers using a heterohybridoma panel, Anim. Genet. 26 (1995) 80-111.

[6] Binns M.M., Holmes N.G., Holliman A., Scott A.M., The identification of polymorphic microsatellite loci in the horse and their use Thoroughbred parentage testing, Brit. Vet. J. 151 (1995) 9-15.

[7] Bellone R.R., Cothran E.G., Ketchum M.S., Genetic variation in the rare donkey breed, Baudet du Poitou, Anim. Genet. 29, (Suppl. 1) (1998) 17.

[8] Bodó I., The minimum number of preserved populations, in: Hodges J. (Ed.), The management of global animal genetic resources, Food and Agriculture Organisation of the United Nations, Rome, 1992, pp. 91-105

[9] Botstein D., White R.L., Skolnick M., Davis R.W., Construction of a genetic linkage map in man using restriction fragment length polymorphisms, Am. J. Hum. Genet. 32 (1980) 314-331.

[10] Breen M., Downs P., Irvin Z., Bell K., Intrageneric amplification of horse microsatellite markers with emphasis on the Przewalski's horse (E. przewalskii), Anim. Genet. 25 (1994) 401-405.

[11] Breen M., Lindgren G., Binns M.M., Genetical and physical assignments of equine microsatellites - First integration of anchored markers in horse genome mapping, Mamm. Genome 8 (1997) 267-273.

[12] Camac R.O., Introduction and Origins of the Donkey, in: Svendsen E.D. (Ed.), The professional handbook of the Donkey, 2nd edn., The Donkey Sanctuary, Sidmouth, Devon, 1989, pp. 1-10.

[13] Clutton-Brock J., A natural history of domestic mammals, Vol. 2. Cambridge University Press, Cambridge, 1987.

[14] Ellegren H., Johansson M., Sandberg K., Andersson L., Cloning of highly polymorphic microsatellite in the horse, Anim. Genet. 23 (1992) 133-142.

[15] Epstein H., Ass, mule and onager, in: Mason I.L. (Ed.), Evolution of domesticated animals, Longman, London and New York, 1984, pp. 174-184.

[16] García Dory M.A., Martínez S., Orozco F., Guía de campo de las razas autóctonas españolas, Alianza Editorial, Madrid, 1990.

[17] Guerin G., Bertaud M., Amigues Y., Characterisation of seven new horse microsatellites: HMS1, HMS2, HMS3, HMS4, HMS5, HMS6, HMS7, and HMS8, Anim. Genet. 25 (1994) 62.

[18] Guo S.W., Thompson E.A., Performing the exact test of Hardy-Weinberg proportions for multiple alleles, Biometrics 48 (1992) 361-372.

[19] Hancock J., Microsatellites and other simple sequences: genomic context and mutational mechanisms, in: Goldstein D., Schlotterer C. (Eds.), Microsatellites. Evolution and applications, Oxford University Press, New York, 1999, pp. 1-10.

[20] Jamieson A., The effectiveness of using codominant polymorphic allelic series for (1) checking pedigrees and (2) distinguishing full-sib pair members, Anim. Genet. 25 (1994) (Suppl. 1), 37-44.

[21] Jordana J., Folch P., The Catalonian donkey breed: program of conservation and improvement of an endangered breed, Arch. Zootec. 47 (1997) 403-409. 
[22] Jordana J., Folch P., Sánchez A., Genetic variation (protein markers and microsatellites) in endangered Catalonian donkeys, Bioch. Syst. Ecol. 27 (1999) 791-798.

[23] Jordana J., Folch P., Aranguren J.A., Microsatellite analysis of genetic diversity in the Catalonian donkey breed, J. Anim. Breed. Genet. 118 (2001) 57-63.

[24] Lorenzo J., Conocimiento y conservación de las razas autóctonas: "El asno Zamorano-Leonés" estudio del estado actual de la raza en la provincia de Zamora; valoración general: Aspectos biopatológicos y funcionales, Tesis Doctoral, Universidad de León, Spain, 1997.

[25] Marklund S., Ellegren H., Eriksson S., Sandberg K., Andersson L., Parentage testing and linkage analysis in the horse using a set of highly polymorphic microsatellites, Anim. Genet. 25 (1994) 19-23.

[26] Moazami-Goudarzi K., Laloë D., Furet J.P., Grosclaude F., Analysis of genetic relationship between 10 cattle breeds with 17 microsatellites, Anim. Genet. 28 (1997) 338-345.

[27] Nei M., Analysis of gene diversity in subdivided populations, Proc. Natl. Acad. Sci., USA 70 (1973) 3321-3323.

[28] Nei M., Estimation of average heterozygosity and genetic distance from a small number of individuals, Genetics 89 (1978) 583-590.

[29] Nei M., Tajima F., Tateno T., Accuracy of estimated phylogenetic trees from molecular data, J. Mol. Evol. 19 (1983) 153-170.

[30] Ota T., DISPAN: Genetic Distance and Phylogenetic Analysis, Pennsylvania State University, University Park, PA, 1993.

[31] Payeras L., Falconer J., Races Autòctones de les Illes Balears, Govern Balear, Palma de Mallorca, 1998.

[32] Raymond M., Rousset F., GENEPOP (Version 3.1): Population genetics software for exact test and ecumenicism, J. Hered. 86 (1995) 248-249.

[33] Romagosa J.A., El Garañón Catalán, Tesis Doctoral, Universidad de Madrid, Spain, 1959.

[34] Saitou N., Nei M., The neighbor-joining method: a new method for reconstructing phylogenetic trees, Mol. Biol. Evol. 4 (1987) 406-425.

[35] SAS ${ }^{\circledR}$ Institute Inc., SAS ${ }^{\circledR}$ User's Guide: Statistics. Version 6.12. Cary, NC, USA, 1996.

[36] Schmid M., Saitbekova C., Dolf G., Genetic diversity in Swiss cattle breeds, J. Anim. Breed. Genet. 116 (1999) 1-8.

[37] Sotillo J.L., Serrano V., Producción Animal 1. Etnología Zootécnica. TebarFlores, Madrid, 1985.

[38] Swofford D.L., Selander R.B., BIOSYS-2: A computer program for the analysis of allelic variation in population genetics and biochemical systematics (Release 2.0), University of Illinois, Urbana, Champaign, IL., 1999.

[39] Takezaki N., Nei M., Genetic distance and reconstruction of phylogenetic trees from microsatellite DNA, Genetics 144 (1996) 389-399.

[40] Yanes G. J., El asno Zamorano-Leonés, una gran raza autóctona. Diputación de Zamora, Spain, 1999.

[41] Van Haeringen H., Bowling A.T., Stott M.L., Lenstra J.A., Zwaagstra K.A., A highly polymorphic horse microsatellite locus: VHL20, Anim. Genet. 25 (1994) 207. 